\title{
Diel variation in the catch of the shrimp Farfantepenaeus duorarum (Decapoda, Penaeidae) and length-weight relationship, in a nursery area of the Terminos Lagoon, Mexico
}

\author{
Roberto Brito, Rolando Gelabert*, Luís Enrique Amador del Ángel, Ángel Alderete \& \\ Emma Guevara \\ Centro de Investigación de Ciencias Ambientales, Facultad de Ciencias Naturales, Universidad Autónoma del \\ Carmen. Av. Laguna de Términos s/n, Col. Renovación 2d $\mathrm{d}^{\mathrm{a}}$ Sección C.P. 24155, Ciudad del Carmen, Camp. México; \\ rbrito@pampano.unacar.mx, rgelabertf@gmail.com*, lamador@pampano.unacar.mx, \\ aalderete@pampano.unacar.mx, eguevara@pampano.unacar.mx \\ * Correspondence
}

Received 02-V-2016. C Corrected 06-IX-2016. Accepted 06-X-2016.

\begin{abstract}
The pink shrimp, Farfantepenaeus duorarum is an important commercial species in the Gulf of Mexico, which supports significant commercial fisheries near Dry Tortugas, in Southern Florida and in Campeche Sound, Southern Gulf of Mexico. There is information about the nictemeral behavior of the pink shrimp related to sunset, what is crucial to more accurate estimation of shrimp population biomass, and to assess the potential of this resource and its proper management. To contribute to the knowledge and the population dynamics of the species, shrimp surveys were conducted in a nursery area near "El Cayo" in the Northeastern part of Terminos Lagoon, Mexico during October 2010. Three sampling sites with substrate covered by submerged vegetation were chosen; two set of samples were collected at each site, one in the morning and the other just after sunset. Three trawls were performed per sampling site using a small otter trawl. A total of 1418 shrimp (between 5.5 to $28.8 \mathrm{~mm}$ Carapace Length (CL)) were collected during the study; 1416 F. duorarum and only two individuals of Litopenaeus setiferus. Shrimps CL and Total Length (TL) were measured in mm and individuals were weighted to the nearest $0.01 \mathrm{~g}$. In general, shrimp biomass and density were significantly higher in all sites during dusk (biomass $=46.36$ g. $100 \mathrm{~m}^{-2}, \mathrm{n}=1344$ ), than daylight samples (biomass $=2.78 \mathrm{~g} .100 \mathrm{~m}^{-2}, \mathrm{n}=72$ ). The One-way ANOVA and the Tukey test performed to evaluate variability in CL found significant differences between sites $(\mathrm{CL}=14.12 \mathrm{~mm}, 12.46 \mathrm{~mm}$ and $15.13 \mathrm{~mm}$, for site 1,2 and 3 respectively, $\mathrm{F}=64.92, \mathrm{P}<0.001)$ which might be related to the substrate type. The length-weight relationships reflected positive allometric growth for juveniles but isometric for subadults and two nonlinear power functions were estimated $\left(\mathrm{W}=0.0004 \mathrm{CL}^{3.157}\right.$ for juveniles, and $\mathrm{W}=0.0009 \mathrm{CL}^{2.902}$ for subadults). The results of the analysis of covariance (ANCOVA) test indicated that the Total Length - Carapace Length (TL-CL) relationships were significantly different between juveniles and subadults, and two linear equations $(\mathrm{TL}=2.615+4.476 \mathrm{CL}$ and $\mathrm{TL}=8.931+4.062 \mathrm{CL}$ for juveniles and subadults respectively) were fitted. It is important that population assessment takes into account the day or night period as a bias factor when sampling the abundance of the juveniles of $F$. duorarum in this important nursery ground of the Campeche Sound. Rev. Biol. Trop. 65 (1): 65-75. Epub 2017 March 01.
\end{abstract}

Key words: behaviour, catchability, Gulf of Mexico, juveniles, Penaeus.

The activity rhythms of marine species may consistently bias demographic evaluation by bottom trawl survey, depending on the time of day (Aguzzi \& Bahamon, 2009). Light is the environmental controlling factor in prawns burrowing during the day and emerging at night (Dall, Hill, Rothlisberg, \& Staples, 1990).
Despite this, management proposals have been frequently based on studies that do not take into account the behavior of the species in the sampling design; this was the case of the juvenile shrimp population studies of Terminos Lagoon in the studies of Gracia and Soto (1990) and Gracia, Hernández, Garcia and Genis (1994). 
Gracia and Soto (1990) stated two decades ago, that more accurate estimations of shrimp population biomass were required to assess the potential of this resource and its proper management in Terminos Lagoon, but until the present study, no serious studies on this shrimp species were proposed for this important nursery ground of the Campeche Sound.

During benthic postlarvae and juvenile stages, penaeid shrimps inhabit shallow and inshore waters such as coastal lagoons, environments that constitute nursery habitats and provide food and refuge for predators (Minello \& Zimmerman, 1991). The pink shrimp (Farfantepenaeus duorarum, Burkenroad, 1939), spawns on the continental shelf, and larvae develop in offshore waters while approaching coastal areas (Munro, Jones, \& Dimitriou, 1968). Postlarvae settle in seagrass beds (Sánchez, 1997), where they grow until they return to the ocean as juveniles or subadults.

It is well known that many penaeid shrimps burrow into the substrate during daytime and are usually active at night (Fuss, 1964; Fuss \& Ogren, 1966; Hughes, 1968, 1969; Reynolds \& Casterlin, 1979; Dall et al., 1990). There is a substantial body of literature concerning circadian rhythms and patterns of locomotor activity of $F$. duorarum. Reynolds and Casterlin (1979) found that locomotor activity increased markedly before sunset, with minimal activity during daylight, coinciding with Hughes (1968, 1969), who stated that the emergence from the substrate of almost all shrimps takes place within a period of 20 to $30 \mathrm{~min}$ at about the time of sunset. Bishop and Herrnkind (1976) studying burying behavior showed that light is the most important factor governing the activity of $F$. duorarum. Recently, Ogburn, Criales, Thompson and Browder (2013) demonstrated that juveniles of $F$. duorarum have an endogenous activity rhythm under constant dark conditions with greater vertical swimming during the night than during the day.

On the other hand, there are studies on $F$. duorarum weight-length relationships (Kutkuhn, 1962; Fontaine \& Neal, 1971; Hutchins, Chamberlain, \& Parker, 1979; Pérez-Castañeda
\& Defeo, 2001), but most of them are based on commercial fisheries or aquaculture activities, and thereby do not always take into account the small juvenile stages in the results. Information in this sense is important, to know the biological characteristics of recruits, juveniles, and subadults in the natural nursery areas, and could help to understand migration in this part of the life cycle of the pink shrimp.

We analyzed day and night variability on the abundance, as well as the allometry, of $F$. duorarum juveniles in Terminos Lagoon, the principal shrimps nursery area in Campeche Bank (Ramírez-Rodríguez, Chávez, \& Arreguín-Sánchez, 2000), which is essential for the evaluation of the shrimp population in Campeche Sound, in the Gulf of Mexico.

\section{MATERIAL AND METHODS}

Shrimp sampling: Three sampling sites (18 $38^{\circ} 15^{\prime \prime} \mathrm{N}-91^{\circ} 42^{\prime} 51^{\prime \prime} \mathrm{W}, 18^{\circ} 38^{\prime} 25^{\prime \prime} \mathrm{N}$ $91^{\circ} 43^{\prime} 0 " \mathrm{~W}$ and $18^{\circ} 39^{\prime} 11^{\prime \prime} \mathrm{N}-91^{\circ} 44^{\prime} 17^{\prime \prime} \mathrm{W}$ ) were chosen near El Cayo in the North central-Northeastern (NC-NE) subsystem of the Terminos Lagoon, Southwest Gulf of Mexico (Fig. 1). The NC-NE subsystem of the lagoon is characterized by polyhaline waters and high densities of macrocrustaceans which are associated with great expanses of submerged aquatic vegetation dominated by Thalassia testudinum (Banks ex König 1805), and including Halodule wrightii (Ascherson 1868), Syringodium filiforme (Kützing in Hohenacker 1860), and red macroalgae (Sánchez, 1997).

Three trawling samplings per site were performed from October 7th to 21rst 2010. During this period, the sunrise occurred between 06:59 and 07:51, and the sunset occurred between 18:41 and 18:51. In each sampling, two trawls were conducted, one in the morning (09:3010:00) and other just after sunset (18:50-19:20).

The trawl was towed for $5 \mathrm{~min}$. from a $7.6 \mathrm{~m}$ boat ( $65 \mathrm{hp}$ outboard engine) at approximately $3.3 \mathrm{~km} . \mathrm{h}^{-1}$. Samples were collected with 10.8 m wide otter trawl with $2 \mathrm{~cm}$ stretched mesh size (equipped with plastic floats in the head rope, small spherical sinkers in the footrope, 


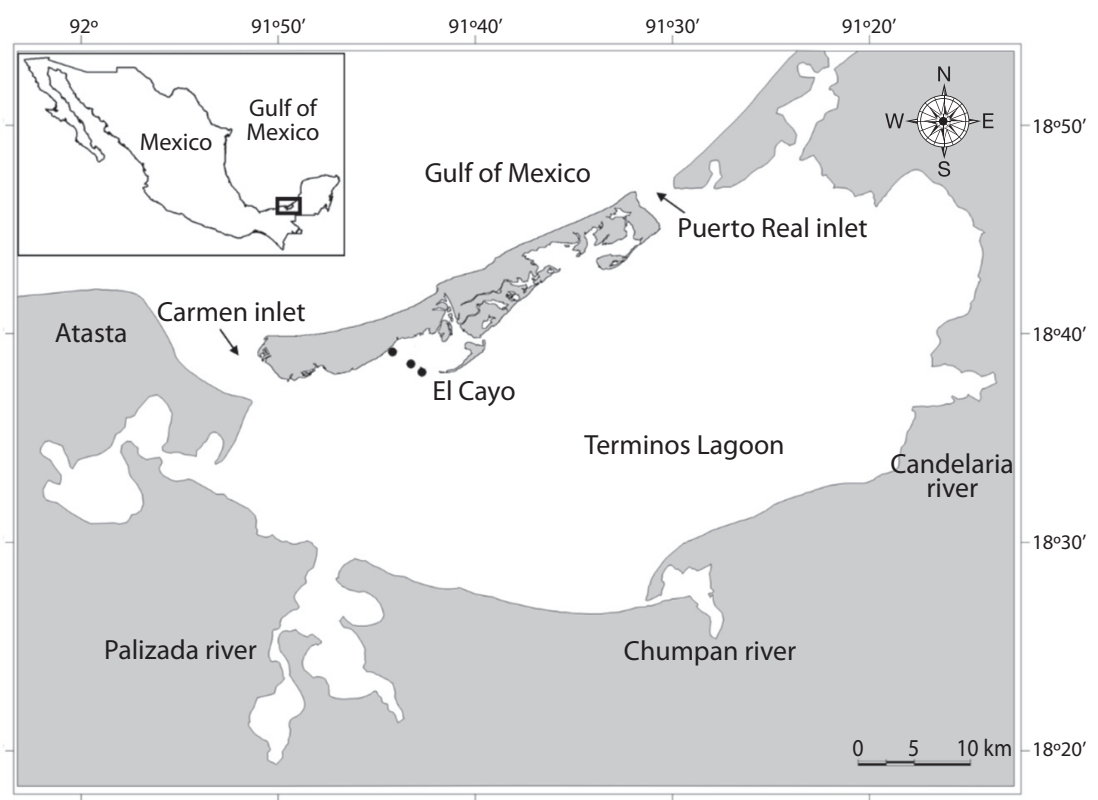

Fig. 1. Sampling sites in Terminos Lagoon, Gulf of Mexico.

and spread with $0.8 \times 0.5 \mathrm{~m}$ wooden doors). The distance between doors $(6.5 \mathrm{~m})$ was calculated following Sparre and Venema (1997) with $\mathrm{X} 2=0.6$. The sampling area (means 1 $800 \mathrm{~m}^{2}$ ) was estimated multiplying the distance between doors by the distance traveled, obtained from a GPS (Global Positioning System) (250 to $300 \mathrm{~m}$ ). Bottom salinity, $\mathrm{pH}$, and conductivity were recorded with a YSI model 63. Dissolved oxygen was measured with a YSI model 55. The temperature was monitored with a HOBO logger (Water temp Pro V2) attached to the trawl entrance and programmed to measure every five seconds. Depth $(\mathrm{cm})$ in each sampling site was also recorded. Sediment samples were taken for grain size analysis. The sediments sampling were randomly performed to obtain four per site. Cylindrical cores of sediment $(10 \mathrm{~cm}$ diameter by $10 \mathrm{~cm}$ deep) were collected with a PVC tube. Particles sizes were calculated in weight percent terms, based on a representative sample of $100 \mathrm{~g}$, which was sorted in sieves of 2000,1000, 149 and 62 $\mu \mathrm{m}$. Finally, sediments were classified according to Folk (1954). Observations for qualitative analysis of submerged vegetation were taken in each sampling site.

Penaeid shrimps captured in each haul were immediately separated and preserved frozen until identification. The keys of PérezFarfante (1970), and Pérez-Farfante and Kensley (1997) were used for species identification. Shrimp carapace length (CL - measured from posterior margin of orbit to posterior border of carapace) and total length (TL - measured from the tip of the rostrum to the end of the telson) both were measured to the nearest $0.1 \mathrm{~mm}$, using an electronic caliper. For TL measures, individuals were manually straightened by the observer to remove the natural curvature of the shrimp body as recommended by Diaz, Smith, Serafy and Ault (2001). Shrimps were weighed to the nearest $0.01 \mathrm{~g}$ (Sartorius BP2100S balance) after removal of excess water with a paper towel. With these values, data of density (ind. $100 \mathrm{~m}^{-2}$ ) and biomass $\left(\mathrm{g} 100 \mathrm{~m}^{-2}\right.$ ) were calculated. Shrimp population components were classified according to Pérez-Castañeda and Defeo (2001) in recruits $(<8 \mathrm{~mm} \mathrm{CL})$, juveniles (between 8 and $15 \mathrm{~mm} \mathrm{CL}$ ) and subadults ( $\geq 15 \mathrm{~mm} \mathrm{CL})$. 
One-way ANOVA was used to test for differences in weight of sediment fractions between sampling sites after arcsin square root data transformation. Shrimp density and biomass were evaluated through two-way ANOVAs using period (day or night) and sites as the main factors, followed by Tukey HSD test. The original values were log-transformed to fulfill ANOVA assumptions. One-way ANOVA was used to test for differences in shrimp CL between the three sampling sites, followed by multiple comparisons Tukey's HSD test for unequal sample size (Zar, 1999). LengthWeight relationship was obtained and fitted to the power function $\left(\mathrm{W}=\mathrm{aCL}^{\mathrm{b}}\right)$, where $\mathrm{W}$ is the wet weight $(\mathrm{g}), \mathrm{CL}$ is the carapace length $(\mathrm{mm})$, and $\mathrm{a}$ and $\mathrm{b}$ are coefficients estimated by least squares, from the linearized equation with log transformation of CL and W (Diaz et al., 2001). Differences in the calculated $b$ values from those expected from isometric growth were evaluated by $t$-tests (Pauly, 1984). The TL-CL relationship was fitted to a linear equation. Only shrimps with a complete rostrum were included in the analysis.

Differences in the TL-CL and W-CL relationships were examined between juveniles and subadults by means of analysis of covariance (ANCOVA; Sokal \& Rohlf, 1981), the Shapiro-Wilk test for analysis of residual between dependent variable and covariate was previously used. Carapace length frequency distributions were made with shrimp grouped into 1 mm CL size classes, using day and night data from all three sampling sites. A $\alpha$-level of 95 $\%$ was chosen for all statistical procedures. All statistical tests were performed using the Statistica (v. 10).

\section{RESULTS}

Although substrate in the three sites was covered by seagrasses and macroalgae, in Site 1 Thalassia testudinum with patches of macroalgae Bryothamnion seaforthii ((Turner) Kützing) and Acanthophora spicifera ((M.Vahl) Børgesen) were predominant; in Site 2 Halodule wrightii and Syringodium filiforme were the main vegetation with lesser presence of $T$. testudinum; and in Site 3, the seagrass density was lower and mixed with sponges and mollusk shells remains. Mud (grains size less than $62 \mu \mathrm{m})$ was represented in significantly higher proportion in Site 2, while, gravel (grains size greater than $2 \mathrm{~mm}$ ), sand (grains size between 62 and $2000 \mu \mathrm{m}$ ) and mud had similar proportions in Sites 1 and 3 (Table 1). Subsequently, sediments were classified as muddy gravel in Site 1 and 3, and slightly gravelly mud in Site 2. Unlike sediment grain size and type of submerged aquatic vegetation, water quality parameters did not differ between sites, patterns of water temperature, salinity and $\mathrm{pH}$ were similar during day and night in the three sampling sites, while dissolved oxygen tends to be higher at night (Table 1).

A total of 1418 shrimps (between 5.5 to $28.8 \mathrm{~mm} \mathrm{CL}$ ) were collected during the study, 1416 were $F$. duorarum and only two individuals belong to Litopenaeus setiferus (Linnaeus, 1767). Shrimp biomass and density were significantly higher during dusk than during daylight samplings in all sites (Fig. 2A and Fig. 2B, Table 2). During the night, shrimp biomass in Site 1 was significantly higher (means= $31.41 \mathrm{~g} 100 . \mathrm{m}^{-2}$, Standard Deviation $(\mathrm{SD})=$ 6.53 ) than in the other sampled sites, (means= 8.05 g. $\left.100 \mathrm{~m}^{-2}, \mathrm{SD}=3.28\right)$ and (means $=6.90$ g. $100 \mathrm{~m}^{-2}, \mathrm{SD}=2.91$ ) for sites 2 and 3 , respectively. Density was higher in Site 1 (means= 15.47 ind $\left.100 \mathrm{~m}^{-2} \mathrm{SD}=3.32\right)$ with intermediate values in Site 2 (means $=5.83$ ind $.100 \mathrm{~m}^{-2}$ $\mathrm{SD}=2.76$ ) and the lowest in Site 3 (means= 2.89 ind $.100 \mathrm{~m}^{-2} \mathrm{SD}=1.21$ ). Shrimps were significantly smaller in Site 2 (means $=12.46$ $\mathrm{SD}=0.164 \mathrm{~mm} \mathrm{CL}$ ) and larger individuals were collected in Site 3 (means $=15.13 \mathrm{SD}=0.178$ $\mathrm{mm} \mathrm{CL}$ ), while intermediate sizes (means= 14.12 $\mathrm{SD}=0.090 \mathrm{~mm} \mathrm{CL}$ ) were found in Site 1. In Site 1 recruits represented $0.4 \%$, juveniles $64.2 \%$, and subadults $35.4 \%$; in Site 2 recruits represented 3.2.0\%, juveniles $77.8 \%$, and subadults $19.0 \%$; while in Site 3, no recruits were captured, juveniles represented $47.9 \%$ and subadults $52.1 \%$. In daylight samplings, recruits represented $1.4 \%$, juveniles $61.4 \%$, 
TABLE 1

Environmental parameters (means values and Standard Error) and sediment type (\% by weight, means values and Standard Deviation), for the three sampling sites in El Cayo ( $\mathrm{DO}=$ dissolved oxygen $)$

\begin{tabular}{|c|c|c|c|c|c|c|c|c|c|}
\hline & \multicolumn{3}{|c|}{ Site 1} & \multicolumn{3}{|c|}{ Site 2} & \multicolumn{3}{|c|}{ Site 3} \\
\hline & means & S.E. & $\mathrm{n}$ & means & S.E. & $\mathrm{n}$ & means & S.E. & $\mathrm{n}$ \\
\hline \multicolumn{10}{|l|}{ Day } \\
\hline Depth (m) & 1.53 & 0.208 & 3 & 1.46 & 0.070 & 3 & 2.27 & 0.268 & 3 \\
\hline Salinity & 14.23 & 1.192 & 3 & 15.35 & 0.534 & 3 & 15.20 & 1.081 & 3 \\
\hline Temperature $\left({ }^{\circ} \mathrm{C}\right)$ & 27.35 & 0.009 & 3 & 27.27 & 0.007 & 116 & 27.71 & 0.015 & 163 \\
\hline DO $\left(m g . L^{-1}\right)$ & 5.17 & 0.540 & 3 & 4.92 & 0.676 & 3 & 6.37 & 0.144 & 3 \\
\hline $\mathrm{pH}$ & 8.25 & 0.142 & 3 & 8.26 & 0.117 & 3 & 8.31 & 0.108 & 3 \\
\hline Conductivity (ms) & 24.55 & 1.915 & 3 & 26.68 & 0.977 & 3 & 26.30 & 1.766 & 3 \\
\hline \multicolumn{10}{|l|}{ Night } \\
\hline Depth (m) & 1.42 & 0.214 & 3 & 2.05 & 0.184 & 3 & 2.53 & 0.158 & 3 \\
\hline Salinity & 14.06 & 1.337 & 3 & 14.70 & 1.320 & 3 & 15.20 & 1.276 & 3 \\
\hline Temperature $\left({ }^{\circ} \mathrm{C}\right)$ & 28.82 & 0.023 & 3 & 28.61 & 0.010 & 148 & 28.10 & 0.010 & 153 \\
\hline DO (mg.L $\left.{ }^{-1}\right)$ & 8.49 & 0.558 & 3 & 7.06 & 0.156 & 3 & 6.94 & 0.095 & 3 \\
\hline $\mathrm{pH}$ & 8.52 & 0.069 & 3 & 8.47 & 0.040 & 3 & 8.46 & 0.092 & 3 \\
\hline Conductivity (ms) & 25.23 & 2.195 & 3 & 24.78 & 3.390 & 3 & 26.59 & 2.014 & 3 \\
\hline \multicolumn{10}{|c|}{ Sediment type (\% by weight) } \\
\hline Gravel & 37.50 & 7.72 & 4 & 26.00 & 2.86 & 4 & 37.50 & 5.92 & 4 \\
\hline sand & 23.10 & 18.66 & 4 & 4.00 & 2.65 & 4 & 27.00 & 6.98 & 4 \\
\hline mud & 39.40 & 18.52 & 4 & 77.67 & 10.97 & 4 & 35.5 & 11.39 & 4 \\
\hline
\end{tabular}

TABLE 2

Results of a two-way ANOVA for biomass (g 100 $\mathrm{m}^{-2}$ ) and for density (ind. $100 \mathrm{~m}^{-2}$ ) of Farfantepenaeus duorarum contrasting the effect of day and night sampling (period) and sampling sites

\begin{tabular}{lcccc}
$\quad$ Effect & DF & MS & F & P \\
Biomass & & & & \\
$\quad$ Period & 1 & 3.006 & 62.73 & $<0.001$ \\
Site & 2 & 0.349 & 7.28 & 0.008 \\
$\quad$ Period x site & 2 & 0.181 & 3.78 & 0.053 \\
$\quad$ Error & 12 & 0.047 & & \\
Density & & & & \\
$\quad$ Period & 1 & 2.105 & 44.28 & $<0.001$ \\
$\quad$ Site & 2 & 0.259 & 5.45 & 0.020 \\
$\quad$ Period x site & 2 & 0.115 & 2.42 & 0.130 \\
Error & 12 & 0.047 & & \\
\hline
\end{tabular}

and subadults $37.1 \%$, whereas at night, there were $1.04 \%$ recruits, $67.12 \%$ juveniles and $31.9 \%$ subadults (Fig. 3) with practically the same proportion of the population components during day and dusk period.

Parameters of the linear equations of TL-CL relationship and for the power function of W-CL relationships were presented in table 3, for W-CL intercepts parameters were obtained via back-transformation. ANCOVA detected significant differences in the TL-CL relationship between juveniles and subadults for the slope coefficients $\left(F_{1,1300}=14.96, \mathrm{P}=\right.$ $0.000)$, but not for the intercepts $\left(F_{1,1300}=0.08\right.$, $\mathrm{P}=0.7773)$. The two estimated equations were $\mathrm{TL}=2.615+4.476 \cdot \mathrm{CL}$ for juveniles and $\mathrm{TL}=$ $8.931+4.062 \cdot \mathrm{CL}$ for subadults. For the W-CL relationships analysis of covariance detected significant differences between juveniles and subadults (for b, $F_{1,1300}=9.58, \mathrm{P}=0.0020$; for a, $\left.F_{1,1300}=0.81, \mathrm{P}=0.3682\right)$. The allometric function for juveniles was $\mathrm{W}=0.0004 \mathrm{CL}^{3.157}$, that for subadults $\mathrm{W}=0.0009 \mathrm{CL}^{2.902}$. The slope was significant different from 3 for juveniles $(t$-test $=4.58, \mathrm{P}<0.05)$, but not for subadults $(t$-test $=1.69, \mathrm{P}>0.05)$.

\section{DISCUSSION}

El Cayo, located in the Northeastern part of Terminos Lagoon is considered a zone with high marine influence (Gracia et al., 1994). 

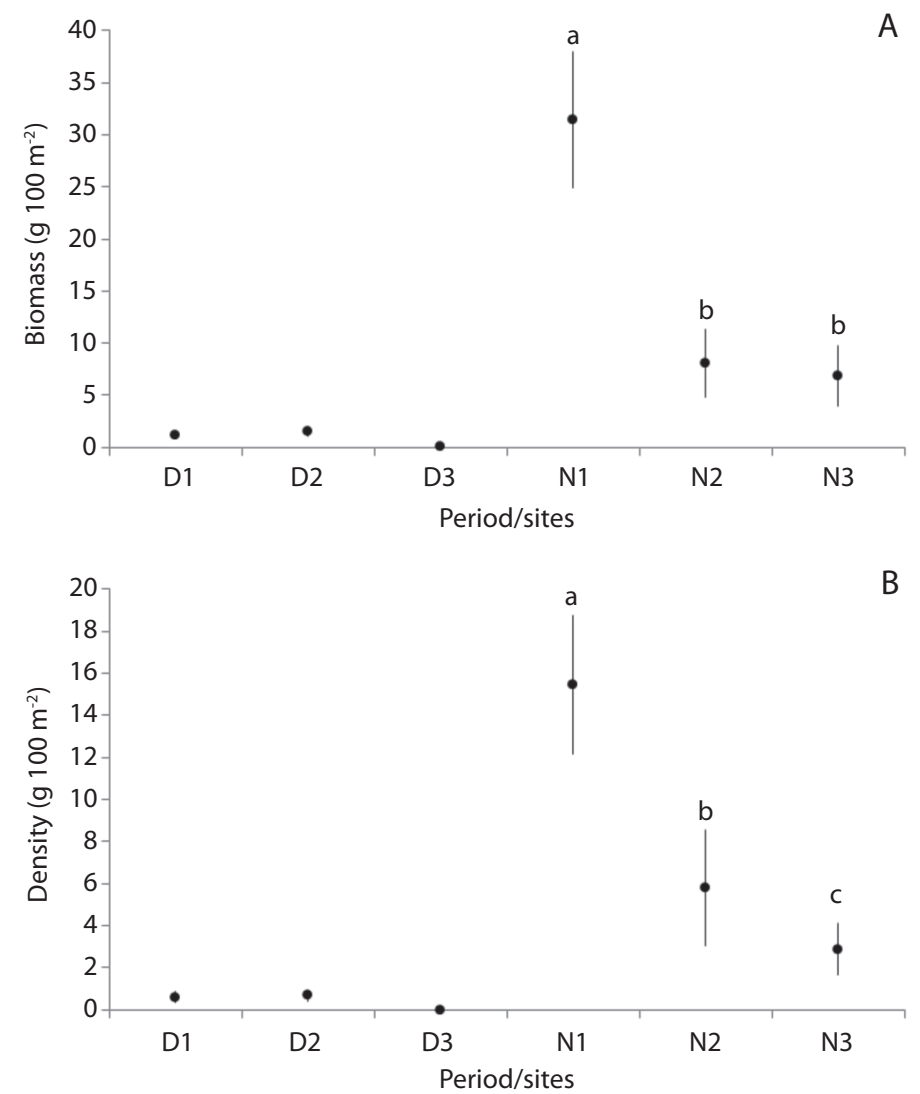

Fig. 2. Variations in Farfantepenaeus duorarum biomass $\left(\mathrm{g} 100 \mathrm{~m}^{-2}\right)(\mathrm{A})$ and density (ind. $\left.100 \mathrm{~m}^{-2}\right)$ (B) in the three sampling sites during day (D) and at night $(\mathrm{N})$ at the corresponding sampling site $(1,2,3)$. Vertical bars represent Standard Deviation. Different letters mean significant difference after Tukey HSD test.

TABLE 3

Regression coefficients for the estimation of Total Length and Weight from CL (for juveniles and subadults)

\begin{tabular}{lcccc}
\multicolumn{1}{c}{ Category } & $\mathrm{n}$ & Intercept & Slope & $\mathrm{r}^{2}$ \\
$\begin{array}{l}\text { Total-length } \\
\text { Juveniles }\end{array}$ & 890 & $2.615(0.742)$ & $4.476(0.059)$ & 0.866 \\
$\quad \begin{array}{l}\text { Subadults } \\
\text { Weight }\end{array}$ & 413 & $8.931(1.522)$ & $4.062(0.089)$ & 0.832 \\
$\quad$ Juveniles & & & & \\
Subadults & 890 & $-3.359(0.037)$ & $3.157(0.034)$ & 0.905 \\
\hline
\end{tabular}

The equations for total length are linear, those for weight log-linear. Values in parentheses are the Standard Error of the coefficients.

Salinity fluctuations in the Lagoon system are directly related to the precipitation regime and associated runoff from rivers (Gracia \& Soto, 1990). Salinity registered at the study sites was in the range of previous studies in the area like that of Yáñez-Arancibia and Lara-Domínguez (1983) (18.3 to 35.8) and Guevara, Álvarez, Mascaró, Rosas and Sánchez (2007) (20-40). 

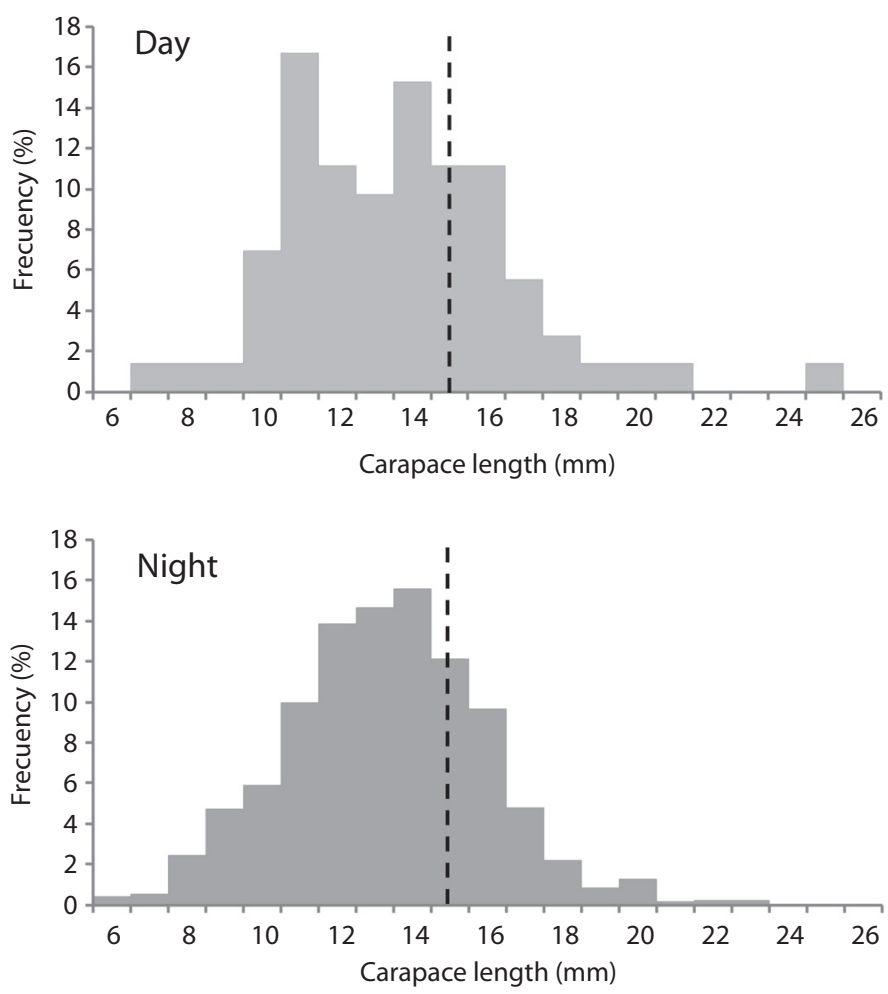

Fig. 3. Carapace Length frequency distributions of Farfantepenaeus duorarum during the day ( $\mathrm{n}=72)$ and night $(\mathrm{n}=1250)$ samplings. Vertical dashed lines divide juveniles ( $<15 \mathrm{~mm} \mathrm{CL})$, and subadults $(\geq 15 \mathrm{~mm}$ CL).

Shrimps species in Terminos Lagoon appear to be spatially segregated, and F. dourarum displays a distribution restricted to areas of polyhaline waters along the inner margin of El Carmen Island, where this study was done (Gracia \& Soto, 1990). This may explain why almost all individuals captured were $F$. duorarum, and coincided with Sánchez (1997) who found that $F$. duorarum represented $97 \%$ of shrimp species using a Renfro beam trawl in this zone.

Higher shrimp biomass and density during dusk than daylight samplings found coincided with Sánchez (1997) who studied the habitat preference of $F$. duorarum in the same zone, and with Stoner $(1988,1991)$, in a different coastal lagoon used as nursery ground for other species of the genus. Field observations of changes in the catchability of penaeids suggested that most of them burrow in the substratum during the day and emerge at night,
(Dall et al., 1990). Even though surveys for population assessment should take into account the sampling period as a factor that potentially biases the abundances obtained (Aguzzi \& Bahamon, 2009), studies in shrimp nursery habitats have been done during day period (Stoner, 1988; Gracia \& Soto, 1990; Gracia et al., 1994; Domínguez, Sánchez, Florido \& Barba, 2003; Barba, Díaz, Aguirre, \& Herrera, 2012). In some studies in Terminos Lagoon and others coastal lagoons in the Gulf of Mexico the exactly hour of sampling is not clear (Alvarez, Gracia, \& Soto, 1987; Ramírez-Rodríguez, Santos-Ortega, \& Navarrete-Del-Proo, 2004; Ocaña-Luna, Hernández-Batún, \& SánchezRamírez, 2008). On the other hand, there are assessments of the abundance and distribution of shrimp where samples were taken at night to coincide with the period of maximum activity for Farfantepenaeus spp. (May-Kú \& Ordóñez-López, 2006; Wakida-Kusunoki, 
García, \& Vázquez, 2008; Pérez-Castañeda et al., 2010; May-Kú \& Ardisson, 2012; May-Kú, Criales, Montero-Muñoz, \& Ardisson, 2014), but none in Terminos Lagoon.

Densities found in the present study were lower than those reported for Madre Lagoon by Wakida-Kusunoki et al. (2008) and PérezCastañeda et al. (2010). However, theses authors took samples using a beam trawl with small mesh size $(1.25 \mathrm{~cm}$, and $1.3 \mathrm{~cm}$ respectively) and found a greater proportion of juveniles (70 to $90 \%$ ), whereas in this study 30 $\%$ of the shrimp were subadults. Because of this difference, we were unable to determine whether densities were different at Terminos Lagoon as compared to Madre Lagoon.

Differences in shrimp CL between sampling sites may be related to substrate type and seagrass composition. The presence of $F$. dourarum associated to estuarine vegetation has been well documented (Costello Allen, \& Hudson, 1986; Corona, Soto, \& Sánchez, 2000; Criales, Yeung, Jones, Jackson, \& Richards, 2003; Pérez-Castañeda et al., 2010; Johnson, Browder, Brown-Eyo, \& Robblee, 2012), and is of utmost importance, as it is a predator of other invertebrates distributed in seagrasses (Sánchez, 1997). This could explain higher proportions of recruits and juveniles in Site 2, with higher presence of mud and predominance of Halodule wrightii and Syringodium filiforme, in contrast with a dominance of subadults in Site 3, where the sediment had larger grain size and seagrass density was lower and composed mainly of Talassia testudinum, mixed with sponges and mollusk shells. This finding is consistent with Pérez-Castañeda et al. (2010) who stated that with the exception of subadults, seagrass and shrimp abundance had a positive linear relationship. In Celestun Lagoon (Yucatan, Mexico), Pérez-Castañeda and Defeo (2001) found that intraspecific interactions in four penaeid species might be reduced by spatial segregation between recruits and juveniles with respect to subadults, as a result of ontogenetic changes in behavior. Recently, May-Kú et al. (2014) found in Yalahau Lagoon (Yucatan, Mexico) that densities of several penaeid shrimp juveniles were related primarily to water salinity, sediment grain size, and biomass and complexity of $T$. testudinum.

The positive allometric growth for $F$. duorarum juveniles obtained in this study, was in agreement with Pérez-Castañeda and Defeo (2002) results for sexually immature shrimp in Celestun Lagoon; nevertheless, differed for subadults, which presented isometric growth. These disagreements may be due to differences between $F$. duorarum populations in different areas of their distribution range, but they need to be corroborated with additional studies.

Although CL is the easiest, fastest, and most reliable length measurement in shrimp (Diaz et al., 2001), many studies used TL for length measurement. Thus, the TL-CL relationship may be a more reliable condition metric for comparisons between different studies. Diaz et al. (2001) found significant differences in this relationship between juveniles and subadults, but not between shrimp sexes. In this study, the $9.24 \%$ decrease in the slope of the TL-CL relationship found for subadults with respect that for juveniles were similar to an $11.5 \%$ reported by Diaz et al. (2001), and indicates a shift in allometry associated with the onset of sexual maturation.

Differences found between sampling sites appear to be related to differences in sediments, and spatial segregation between recruits and juveniles with respect to subadults. The shrimp density obtained in this study when sampling was performed during the nightly period was 10 to 80 -fold than the one obtained from diurnal samplings. Although these results corroborated that to assess shrimps density studies in nursery areas, it is very important to take into account the period of the day. Nevertheless, this important issue has not been taken into account in juvenile shrimp studies in Terminos Lagoon and other important nursery areas of the Campeche Sound. In addition, future studies should take in consideration the use of sampling gears that allow the capture of the different shrimp population components in order to make reliable comparisons of shrimp density 
of each size class in different nursery habitats of the Bay of Campeche.

\section{ACKNOWLEDGMENTS}

Authors recognize financial support given by Universidad Autónoma del Carmen. We thank to Rosela Pérez Ceballos, Professor CONACYT, Institute of Marine Sciences and Limnology, Station "El Carmen" UNAM, by drawing figure concerning the study area.

\section{RESUMEN}

Variación diaria en la captura del camarón Farfantepenaeus duorarum (Decapoda: Penaeidae) y relaciones largo peso en un área de cría de la Laguna de Términos, México. El camarón rosado Farfantepenaeus duorarum es una especie de importancia comercial en el Golfo de México, mantiene pesquerías comerciales relevantes cerca de Dry Tortugas en el Sureste de la Florida y en la Sonda de Campeche, Sureste del Golfo de México. Existe información acerca de la conducta nictemeral del camarón rosado relacionada con la puesta del sol, lo cual resulta crucial para una estimación más precisa de las poblaciones y de la biomasa así como para evaluar el potencial del recurso y de su adecuado manejo. Para contribuir con el conocimiento de la dinámica de poblaciones de esta especie de camarón, se realizó un estudio en una zona de cría cerca de "El Cayo", área del Noreste de la Laguna de Términos, México, durante octubre 2010. Se seleccionaron tres sitios de muestreo cubiertos con vegetación sumergida. En cada sitio se tomó una muestra en la mañana y otra justamente después de la puesta del sol. Se realizaron tres arrastres por sitio de muestreo usando una pequeña red de arrastre. Durante el estudio fueron recolectados un total de 1418 camarones (entre 5.5 y 28.8 mm longitud del carapacho (LC)); 1416 Farfantepenaeus duorarum y dos individuos de Litopenaeus setiferus. Se midió la LC y la longitud total (LT) de los camarones (mm) y se pesaron con una precisión de $0.01 \mathrm{~g}$. En general, la biomasa y la densidad fueron significativamente mayores en todos los sitios durante el anochecer (biomasa $=446.36$ g. $100 \mathrm{~m}^{-2}, \mathrm{n}=1344$ ) que durante el día (biomasa $=2.78$ g. $100 \mathrm{~m}^{-2}, \mathrm{n}=72$ ). El ANOVA y la prueba Tukey realizada para evaluar la variación en LC en los diferentes sitios, mostraron diferencias significativas $(\mathrm{LC}=14.12 \mathrm{~mm}, 12.46$ $\mathrm{mm}, 15.13 \mathrm{~mm}$, para los sitios 1,2 and 3 respectivamente, $\mathrm{F}=64.92, \mathrm{P}<0.001$ ), lo cual puede estar relacionado con el tipo de sustrato. La relación de la longitud con el peso refleja un crecimiento alométrico positivo para los juveniles pero no para los subadultos por lo que se estimaron dos funciones no lineales $\left(\mathrm{Peso}=0.0004 \mathrm{LC}^{3.157}\right.$ para juveniles and $\mathrm{Peso}=0.0009 \mathrm{LC}^{2.902}$ para subadultos). Los resultados del ANCOVA realizados indicaron que la relación Largo Total-Longitud del Carapacho (LT-LC) fue significativamente diferente entre juveniles y subadultos y se ajustaron a dos ecuaciones lineales $(\mathrm{LT}=2.615+4.476 \mathrm{LC}$ y $\mathrm{LT}=$ $8.931+4.062$ LC, para juveniles y subadultos respectivamente). Para la evaluación de la población es importante que se considere el momento del muestreo como un factor que afecta la estimación de la abundancia de juveniles de F. duorarum en esta importante zona de cría de la Sonda de Campeche.

Palabras clave: conducta, captura, Golfo de México, juveniles, Penaeus.

\section{REFERENCES}

Aguzzi, J., \& Bahamon, N. (2009). Modeled day-night biases in decapod assessment by bottom trawling survey. Fisheries Research, 100(3), 274-280.

Álvarez, F, Gracia, A., \& Soto, L. A. (1987). Crecimiento y mortalidad de las fases estuarinas del camarón rosado Penaeus (Farfantepenaeus) duorarum Burkenroad, 1939 en la Laguna de Términos, Campeche. Anales del Instituto de Ciencias del Mar y Limnología, Universidad Nacional Autónoma de México, (14), 115-137.

Barba, E., Díaz, S., Aguirre, A., \& Herrera, P. (2012). Macrocrustáceos bentónicos de los sistemas lagunares Chantuto-Panzacola y Carreteras-Pereyra, Chiapas, México. Recursos Acuáticos Costeros del Sureste, I, 371-395.

Bishop, J. M., \& Herrnkind, W. F. (1976). Burying and molting of pink shrimp, Penaeus duorarum (Crustacea: Penaeidae), under selected photoperiods of white light and UV-Light. The Biological Bulletin, 150(2), 163-182.

Corona, A., Soto, L. A., \& Sánchez, A. J. (2000). Epibenthic amphipod abundance and predation efficiency of the pink shrimp Farfantepenaeus duorarum (Burkenroad, 1939) in habitats with different physical complexity in a tropical estuarine system. Journal of Experimental Marine Biology and Ecology, 253(1), 33-48.

Costello, T. J., Allen, D. M., \& Hudson, J. H. (1986). Distribution, seasonal abundance, and ecology of juvenile northern pink shrimp, Penaeus duorarum, in the Florida Bay area. USA: US Department of Commerce, National Oceanic and Atmospheric Administration, National Marine Fisheries Service, Southeast Fisheries Center. Retrieved from http:// docs.lib.noaa.gov/noaa_documents/NMFS/SEFSC/ TM_NMFS_SEFSC/NMFS_SEFSC_TM_161.pdf

Criales, M. M., Yeung, C., Jones, D. L., Jackson, T. L., \& Richards, W. J. (2003). Variation of oceanographic processes affecting the size of pink shrimp 
(Farfantepenaeus duorarum) postlarvae and their supply to Florida Bay. Estuarine, Coastal and Shelf Science, 57(3), 457-468.

Dall, W., Hill, B. J., Rothlisberg, P. C., \& Staples, D. J. (1990). The Biology of the Penaeidae (Advances in Marine Biology, Vol. 27). London, England: Elsevier Academic Press.

Diaz, G. A., Smith, S. G., Serafy, J. E., \& Ault, J. S. (2001). Allometry of the growth of pink shrimp Farfantepenaeus duorarum in a subtropical bay. Transactions of the American Fisheries Society, 130(2), 328-335.

Domínguez, J. C., Sánchez, A. J., Florido, R., \& Barba, E. (2003). Distribución de macrocrustáceos en Laguna Mecoacán, al sur del Golfo de México. Hidrobiológica, 13(2), 127-136.

Folk, R. L. (1954). The distinction between grain size and mineral composition in sedimentary-rock nomenclature. The Journal of Geology, 62, 344-359.

Fontaine, C. T., \& Neal, R. A. (1971). Length-weight relations for three commercially important penaeid shrimp of the Gulf of Mexico. Transactions of the American Fisheries Society, 100(3), 584-586.

Fuss, C. M. (1964). Observations on burrowing behavior of the pink shrimp, Penaeus duorarum Burkenroad. Bulletin of Marine Science, 14(1), 62-73.

Fuss, C. M., \& Ogren, L. H. (1966). Factors affecting activity and burrowing habits of the pink shrimp, Penaeus duorarum Burkenroad. Biological Bulletin, 130(2), 170-191.

Gracia, G. A., \& Soto, L. A. (1990). Populations study of the penaeid shrimp of Terminos Lagoon, Campeche, México. Anales del Instituto de Ciencias del Mar y Limnología, UNAM, 17(2), 241-255.

Gracia, A., Hernández, G., García, R., \& Genis, J. (1994). Eficiencia de redes epibenticas de barra tipo renfro para muestreo de camarones peneidos. Ciencias Marinas, 20(3), 351-369.

Guevara, E., Álvarez, H., Mascaró, M., Rosas, C., \& Sánchez, A. (2007). Hábitos alimenticios y ecología trófica del pez Lutjanus griseus (Pisces: Lutjanidae) asociado a la vegetación sumergida en la Laguna de Términos, Campeche, México. Revista de Biología Tropical, 55(3-4), 989-1004.

Hughes, D. A. (1968). Factors controlling emergence of pink shrimp (Penaeus duorarum) from the substrate. The Biological Bulletin, 134(1), 48-59.

Hughes, D. A. (1969). Evidence for the endogenous control of swimming in pink shrimp, Penaeus duoraum. The Biological Bulletin, 136(3), 398-404.

Hutchins, D. L., Chamberlain, G. W., \& Parker, J. C. (1979). Length-weight relations for several species of penaeid shrimp cultured in ponds near Corpus Christi, Texas. In Proceedings of the World Mariculture Society Vol. 10 (pp. 565-570). Wiley Online Library. Retrieved from doi/10.1111/j.1749-7345.1979. tb00054.x/abstract

Johnson, D. R., Browder, J. A., Brown-Eyo, P., \& Robblee, M. B. (2012). Biscayne Bay Commercial Pink Shrimp, Farfantepenaeus duorarum, Fisheries, 19862005. Marine Fisheries Review, 74(4), 28-43.

Kutkuhn, J. H. (1962). Gulf of Mexico commercial shrimp populations-trends and characteristics, 1956-59. Fishery Bulletin, 62, 546-554. Retrieved from http:// repositories.tdl.org/tamug-ir/handle/1969.3/20194

May-Kú, M. A., \& Ordóñez-López, U. (2006). Spatial patterns of density and size structure of penaeid shrimps Farfantepenaeus brasiliensis and Farfantepenaeus notialis in a hypersaline lagoon in the Yucatan Peninsula, Mexico. Bulletin of Marine Science, 79(2), 259-271.

May-Kú, M. A., \& Ardisson, P. L. (2012). Distribución espacial de camarones peneidos en la laguna Yalahau, Quintana Roo. In A. J. Sánchez, X. Chiappa-Carrara \& R. Brito (Eds.), Recursos Acuáticos Costeros Del Sureste: Tendencias Actuales En Investigación $Y$ Estado Del Arte (pp. 48-62). México: CONACYT, Gobierno del Estado de Yucatán, Universidad Nacional Autónoma de México, Red para el Conocimiento de los Recursos Costeros del Sureste.

May-Kú, M. A., Criales, M. M., Montero-Muñoz, J. L., \& Ardisson, P. L. (2014). Differential use of Thalassia testudinum habitats by sympatric penaeids in a nursery ground of the southern Gulf of Mexico. Journal of Crustacean Biology, 34(2), 144-156. doi10.1163/1937240X-00002214

Minello, T. J., \& Zimmerman, R. J. (1991). The role of estuarine habitats in regulating growth and survival of juvenile penaeid shrimp. Frontiers of Shrimp Research, 1-16.

Munro, J. L., Jones, A. C., \& Dimitriou, D. (1968). Abundance and distribution of the larvae of the pink shrimp (Penaeus duorarum) on the Tortugas shelf of Florida, August 1962-0ctober 1964. Fishery Bulletin, 67(1), 165-181.

Ocaña-Luna, A., Hernández-Batún, G., \& Sánchez-Ramírez, M. (2008). Abundancia y distribución de juveniles de Farfantepenaeus aztecus (Ives 1891), F. duorarum (Burkenroad 1939) y Litopenaeus setiferus (Linnaeus 1767) en la Laguna Madre, Tamaulipas, México. Hidrobiológica, 18(3), 199-208.

Ogburn, M. B., Criales, M. M., Thompson, R. T., \& Browder, J. A. (2013). Endogenous swimming activity rhythms of postlarvae and juveniles of the penaeid shrimp Farfantepenaeus aztecus, Farfantepenaeus duorarum, and Litopenaeus setiferus. 
Journal of Experimental Marine Biology and Ecology, 440, 149-155.

Pauly, D. (1984). Fish population dynamics in tropical waters: a manual for use with programmable calculators (Vol. 8). Philippines: WorldFish. Retrieved from https://books.google.com/books?

Pérez-Farfante, I. (1970). Diagnostic characters of juveniles of the shrimps Penaeus aztecus aztecus, $P$. duorarum duorarum, and P. brasiliensis (Crustacea, Decapoda, Penaeidae). Special Scientific ReportFisheries, 599, 1-26.

Pérez-Farfante, I., \& Kensley, B. (1997). Penaeoid and Sergestoid shrimps and prawns of the world. Keys and diagnoses for the families and genera. France: Memoires Du Museum National d'Histoire Naturelle. Retrieved from http://agris.fao.org/agris-search/ search.do? recordID $=$ FR1997004308

Pérez-Castañeda, R., \& Defeo, O. (2001). Population variability of four sympatric penaeid shrimps (Farfantepenaeus spp.) in a tropical coastal lagoon of Mexico. Estuarine, Coastal and Shelf Science, 52(5), 631-641.

Pérez-Castañeda, R., \& Defeo, O. (2002). Morphometric relationships of penaeid shrimps in a coastal lagoon: spatio-temporal variability and management implications. Estuaries, 25(2), 282-287.

Pérez-Castañeda, R., Blanco-Martínez, Z., Sánchez-Martínez, J. G., Rábago-Castro, J. L., Aguirre-Guzmán, G., \& de la Luz Vázquez-Sauceda, M. (2010). Distribution of Farfantepenaeus aztecus and F. duorarum on submerged aquatic vegetation habitats along a subtropical coastal lagoon (Laguna Madre, Mexico). Journal of the Marine Biological Association of the United Kingdom, 90(3), 445-452.

Ramírez-Rodríguez, M., Chávez, E. A., \& Arreguín-Sánchez, F. (2000). Perspective of the pink shrimp (Farfantepenaeus duorarum Burkenroad) fishery of Campeche Bank, México. Ciencias Marinas, 26(1), 97-112.

Ramírez-Rodríguez, M., Santos-Ortega, Y., \& Navarrete-Del-Proo, A. (2004). Juvenile pink shrimp, Farfantepenaeus duorarum (Burkenroad, 1939): length composition in three nursery areas in Campeche Sound, Gulf of Mexico. Crustaceana, 77(9), 1107-1116.

Reynolds, W. W., \& Casterlin, M. E. (1979). Diel activity of the pink shrimp Penaeus duorarum. Hydrobiologia, 66(3), 223-226. doi 10.1007/BF00020903

Sánchez, A. J. (1997). Habitat preference of Penaeus duorarum Burkenroad (Crustacea: Decapoda) in a tropical coastal lagoon, southwest Gulf of Mexico. Journal of Experimental Marine Biology and Ecology, 217(1), 107-117.

Sokal, R. R., \& Rohlf, F. J. (1981). Biometry (2nd edn). New York: W. H. Freeman.

Sparre, P., \& Venema, S. C. (1997). Introducción a la evaluación de recursos pesqueros tropicales (Documento Técnico de Pesca 306/1). Guatemala: FAO, Universidad de San Carlos de Guatemala. Retrieved from http://www.sidalc.net/cgi-bin/wxis. exe/?IsisScript=FAUSAC.xis\&method=post\&format $\mathrm{o}=2$ \& cantidad $=1$ \& expresion $=\mathrm{mfn}=026438$

Stoner, A. W. (1988). A nursery ground for four tropical Penaeus species: Laguna Joyuda, Puerto Rico. Marine Ecology Progress Series. Oldendorf, 42(2), 133-141.

Stoner, A. W. (1991). Diel variation in the catch of fishes and penaeid shrimps in a tropical estuary. Estuarine, Coastal and Shelf Science, 33(1), 57-69.

Wakida-Kusunoki, A., García, L., \& Vázquez, N. G. (2008). Abundance of the commercial penaeid shrimp juveniles in the North zone of Laguna Madre, Mexico. Hidrobiológica, 18, 85-87.

Yáñez-Arancibia, A., \& Lara-Domínguez, A. L. (1983). Dinámica ambiental de la Boca de Estero Pargo y estructura de sus comunidades de peces en cambios estacionales y ciclos de 24-hrs. (Laguna de Términos, sur del Golfo de México). Anales del Instituto de Ciencias del Mar y Limnología, UNAM, 10, 85-116.

Zar, J. H. (1999). Biostatistical Analysis (4th ed.). New Jersey, USA: Prentice Hall. 
